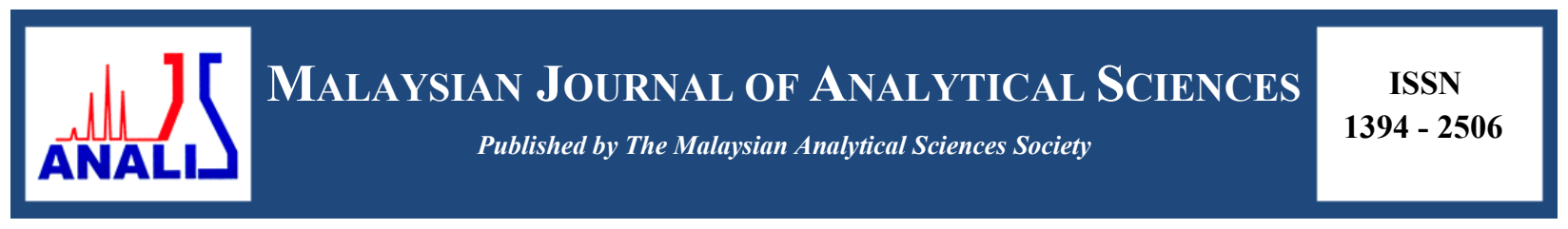

\title{
EFFECT OF VARIOUS POWER LEVEL AND DIFFERENT RATIO OF FRUIT TO WATER IN OIL PALM FRUITS MICROWAVE STERILIZER
}

\author{
(Kesan Pelbagai Tahap Kuasa dan Nisbah Berlainan Buah terhadap Air dalam Pensterilan \\ Gelombang Mikro Buah Kelapa Sawit) \\ Norashikin Ahmad Zamanhuri*, Norazah Abd Rahman, Noor Fitrah Abu Bakar \\ Faculty of Chemical Engineering, \\ Universiti Teknologi MARA, 40450 Shah Alam, Selangor, Malaysia \\ *Corresponding author: shikin282103@gmail.com
}

Received: 28 November 2016; Accepted: 5 February 2017

\begin{abstract}
The aim of this paper is to investigate the effect of using various power level and different ratio of fruit to water in microwave sterilizer in order to acquire the shortest time of the fruit to be completely detached from the spikelet. Normally, the palm oil fruits processing uses steam heating for sterilization of oil palm fruit brunches. The conventional steam treatment of sterilization produces large amount of waste water from the palm oil mill process. Also, this process is classifying as crucial process with the intention of inactivate the lipolytic enzyme as prevention to the increase of free fatty acids (FFA) in oil. Therefore, microwave irradiation is used in this research for solving this problem and improving of palm oil fruit quality prior to extraction of crude palm oil (CPO). The optimal condition was $800 \mathrm{~W}$ for 6 minutes of $100 \%$ strip of fruit from the spikelet with $1: 0.5$ ratio by means of $4.08 \%$ of FFA. It can be concluded that microwave radiation is suitable for quick detachment of the fruitlet from the spikelet and fruit loosening performed without kernels started to turn brown and appeared dehydrated. Throughout the trial, the quality of the oil extracted from the microwave sterilized spikelets in terms of the FFA percentage was acceptable. The quality of the oil is excellent, with free fatty acids of the crude oil generally below $5 \%$.
\end{abstract}

Keywords: oil palm fruits, sterilisation, microwave, stripping, free fatty acids

\begin{abstract}
Abstrak
Tujuan kertas ini adalah untuk mengkaji kesan menggunakan pelbagai tahap kuasa dan nisbah yang berbeza buah-buahan terhadap air dalam pensterilan gelombang mikro untuk memperoleh masa yang singkat buah-buahan terpisah lengkap daripada spikelet itu. Biasanya, pemprosesan buah kelapa sawit menggunakan pemanasan stim untuk tujuan pensterilan. Rawatan wap konvensional pensterilan menghasilkan sejumlah besar air sisa daripada proses kilang minyak sawit. Juga, proses ini diklasifikasikan proses sebagai penting dengan niat untuk menyahaktifkan enzim lipolitik sebagai pencegahan kepada peningkatan asid lemak bebas (FFA) dalam minyak. Oleh itu, penyinaran gelombang mikro digunakan dalam kajian ini untuk menyelesaikan masalah dan meningkatkan kualiti buah kelapa sawit sebelum pengekstrakan minyak sawit mentah (MSM). Keadaan optimum adalah 800W untuk 6 minit daripada 100\% lerai buah dari spikelet dengan nisbah 1: 0.5 bagi $4.08 \%$ FFA. Dapat disimpulkan bahawa radiasi gelombang mikro adalah sesuai untuk peleraian cepat buah dari spikelet dan ia dapat dilakukan tanpa biji mula bertukar coklat dan kelihatan kering. Sepanjang ujikaji, kualiti minyak yang diekstrak daripada gelombang mikro disterilkan dari segi peratusan FFA boleh diterima. Kualiti minyak adalah yang baik, dengan asid lemak bebas minyak mentah biasanya di bawah $5 \%$.
\end{abstract}

Kata kunci: buah kelapa sawit, pensterilan, gelombang mikro, pelucutan, asid lemak bebas 


\section{Introduction}

Malaysia is one of the countries that successfully beneficiaries of the oil palm industry and being responsible for uprising this industry globally through significant contributions and continuous commitment. In summary, oil palm processing in mill involves the receiving of fresh fruit bunches from the plantations, sterilizing and separating of the bunches to free the palm fruits, digesting and mashing of the fruits and pressing out the crude palm oil, clarification, purification, drying and storage[1,2]. Pre-treatments are occasionally crucial with the purpose of overcome difficulties in material handling throughout subsequent processing steps. Sterilization process of oil palm fruits is categorize as the -first step in palm oil milling process prior to extract crude palm oil as well as identified steam treatment. At this moment, the conditions to apply sterilization is within range of $15-45$ psi of pressure, $70-90$ min of cooking time and at temperature more than $100^{\circ} \mathrm{C}[3,4]$.

Crude palm oil (CPO) generated from this current process has good quality. Nonetheless, palm oil mill effluent (POME) known as hazardous to the surroundings has produced abundant waste water [5]. POME will be generated from three main sources for each tonne, sterilizer condensate, sludge separator and hydrocyclone waste with $27 \%$, $44 \%$ and $29 \%$, respectively [6, 7]. Even though POME is a non-toxic liquid waste with horrible smell and its chemical oxygen demand (COD) and biochemical oxygen demand (BOD) value are relatively high, thus the great cost of treatment was required to meet environmental standard [8]. To solve the problem of the generated POME, alternative methods may also be encountered throughout microwave oven to apply as a treatment to the oil palm fruits with the minimal water usage.

In the conventional milling process, fresh fruit bunches are loaded in cages and pushed into sterilizers where they are cooked. The process seizures oil quality deterioration due to enzymatic activity. Enzymatic lipolysis of the oil, which may result in a rise of free fatty acids (FFA) in the fruits, is halted immediately upon sterilization of the bunches. High amount of free fatty acids that the oil might become unfit for human consumption without appropriate refining. Sterilisation also facilitates the stripping of fruits from the bunch and the extraction of oil and kernel. At present, screw press and hydraulic presser technology has been carried out in palm oil mill processing [7, 9] that is completed after the fresh fruit bunches run through steam treatment. However, current method carried out in mill for oil extraction, generates residual oil or leftover oil about 3-7\%, which is eventually gathered as POME and proven to be dangerous to the environment $[10,11]$. Therefore, an effort is thus made in this study to look into the prospect of utilization of microwave heating for the first stage of the process.

Numerous experiments have established that the solventised fibres from soxhlet extraction were discovered to be very dry, brittle and completely decolourised, indicating complete exhaustion of oil [3, 12-15] . The clarification step in the conventional palm oil milling process which uses large amount of water, was fully omitted, bringing to cleaner and higher quality crude palm oil. Oil with higher content of vitamin $\mathrm{E}$ and carotenes produce from this solvent extraction method, will be more stable and having longer shelf life. The current pretreatment using microwave could also offer as an alternative route for phytonutrients recovery. It is also a clean technology due to minimal water effluent discharge. They also wrap up that milling would then be a process not only for the recovery of trapped crude palm oil in fibres after digesting process, but also for the recovery of high value added nutraceuticals too. This would enhance the economics of palm oil production.

To the best of our comprehension, the influence of microwave extraction cum sterilisation for the crude palm oil from oil palm fruits has not been reported yet. And also, less emphasis on stripping irradiation time of the sterilised oil palm bunch at various power levels, ratio and quality of the fruits after microwave sterilization is reported in published literature. Thus, the aims of the present research are: (1) to study the effect of using various power level to improve the stripping efficiency with shorter irradiating time or comparable to conventional method, (2) to discover effect of different ratio of fruit to water in microwave sterilizer in order to get the the shortest time of the fruit to be completely detached from the spikelet as well as good mesocarp and kernel condition. For this purpose, all parameters were individually investigated and then combined and optimized, finally (3) to analyse the quality of the oil extracted from the microwave sterilized oil palm spikelets in terms of the FFA percentage whether acceptable, below 5\% [14, 15]. 


\section{Materials}

\section{Materials And Methods}

Fresh palm fruit was obtained from local oil palm plantation from open areas in Selangor, Malaysia. Fresh fruit bunch was chopped into fruit spikelets and $200 \mathrm{~g}$ of each was weighed [12]. The sample was kept in a dry place ready for sterilization [16]. It is of utmost importance that the chopped fruits to be subjected to immediate sterilization in order to deactivate the lipase activity [17]. The FFA content from the fruit spikelets with major damage can reach above $5 \%$ if there was no pre- treatment process done immediately [13].

\section{Microwave sterilisation experiments}

Only several spikelet of bunch were selected and weighed before undergoing microwave heating (microwave oven Panasonic Commercial, model: NN-ST651M, 1000 Watt frequency of $2450 \mathrm{MHz}$ ) for 2 minutes intervals time until $100 \%$ stripping reach. The trials were repeated 3 times for 100, 300, 400, 600 and 800W of microwave power level. The condition and appearance of the center of the kernel was noted. The fruits at the spikelets were detached with a slight push of a finger $[12,16]$ until the fruits were completely detached from the spikelet. The stripping efficiency was then determined according to Equation 1.

$$
\% \text { Stripping Efficiency, } S_{\text {eff }}=\frac{F_{1}}{F_{1}+F_{r}} \times 100 \%
$$

where $S_{\text {eff }}$, the percentage of stripping efficiency, $F_{1}$, the number of fruits loosened from the spikelet after stripping, and $F_{r}$, the number of fruits remained at the spikelet after stripping.

In addition, study is necessary on a combined system by using combination of moisture and heat in a microwave so that sterilisation can be conducted at shorter time with $100 \%$ fruits stripping efficiency. Effect of water ratio (m:v) at 1:0.5, 1:1 and 1:2 was also investigated for each batch of microwave revealing duration, where the ratio is fruits mass (gram) to water volume ( $\mathrm{ml}$ ). As the exposure duration of dry microwave was extended, there was significant increase in drying, cracking and browning effect on the mesocarp and kernel. This step on combination of moisture and heat in a microwave is essential to give them the initial moisture throughout sterilization process with very minimal water added [19 - 21]. The important benefit of a microwave is the 'time efficiency'. So, the energy and time are saved.

The percentage of free fatty acids was measured by means of Soxhlet extraction, where $20 \mathrm{~g}$ of mesocarp oil palm was weighed into a cellulose thimble $(30 \mathrm{~mm}$ x $77 \mathrm{~mm}$, Whatman, Maidstone, UK) and placed in a Soxhlet device. Most mesocarp samples should be predried at $102 \pm 2{ }^{\circ} \mathrm{C}$ for $1-2$ hours to optimize the oil extraction. Water in the sample can decrease the efficiency of the solvent extraction, resulting in low fat recoveries. Two hundred milliliters of hexane (at $63-65^{\circ} \mathrm{C}$ ) were used as the solvent and the extraction was performed for $4-6$ hours until the yellow color has disappeared $[13,18]$.

\section{Determination of free fatty acid content}

The free fatty acid content was measured using the titration method as written in the MPOB Test Method [23] with some modification [13]. An amount $2 \mathrm{~g}$ of preheated oil (about $50{ }^{\circ} \mathrm{C}$ ) was weighed in a clean beaker and mixed with $50 \mathrm{ml}$ Isopropyl alcohol. The solution was neutralized by titration of $0.100 \mathrm{~N}$ sodium hydroxide $(\mathrm{NaOH})$. The percentage of FFA content was calculated using this Eq. (2):

$$
\% \mathrm{FFA}=\frac{25.6 \mathrm{xVxN}}{\mathrm{w}}
$$

where: $V=$ volume of sodium hydroxide used, $N=0.1005 \mathrm{~N}$ Normality (concentration) of sodium hydroxide used, $w=$ Weight of oil used

\section{Results and Discussion \\ Preliminary study: Optimization of microwave power level} Figures 1 shows effect on stripping efficiency of oil palm spikelet in relation various microwave power level of 100 to 800 Watt with fruit spikelets mass of $200 \mathrm{~g}$. It can be observed that, the shortest time to reach completely fruits 
detachment is at 800 Watt for only 4 minutes and the lengthiest irradiating time to reach $100 \%$ stripping is at 100 Watt. Immediate microwave sterilization is the ultimate importance in order to deactivate the lipase activity that later will increase the FFA percentage. In most of the microwave study, power and material always represent by power density which expressed number of power applies to the oil palm fruits sample per gram. High power density expressed effectiveness of moist microwave sterilization process due to maximum microwave energy being absorbed by small sample [24]. Overheating of the bunch portions will further deteriorate the stripping efficiency [18] as indicated by declining stripping trend as the heating time was prolonged after achieving highest stripping efficiency after 12 minutes for $2 \mathrm{~kW}$, after 14 minutes for $1.5 \mathrm{~kW}$ and after 16 minutes for $1 \mathrm{~kW}$. For microwave sterilization studied by [24], the stripping efficiency at elevated power level are $27 \%, 58.5 \%$ and $61 \%$, after 16 minutes of exposure time.

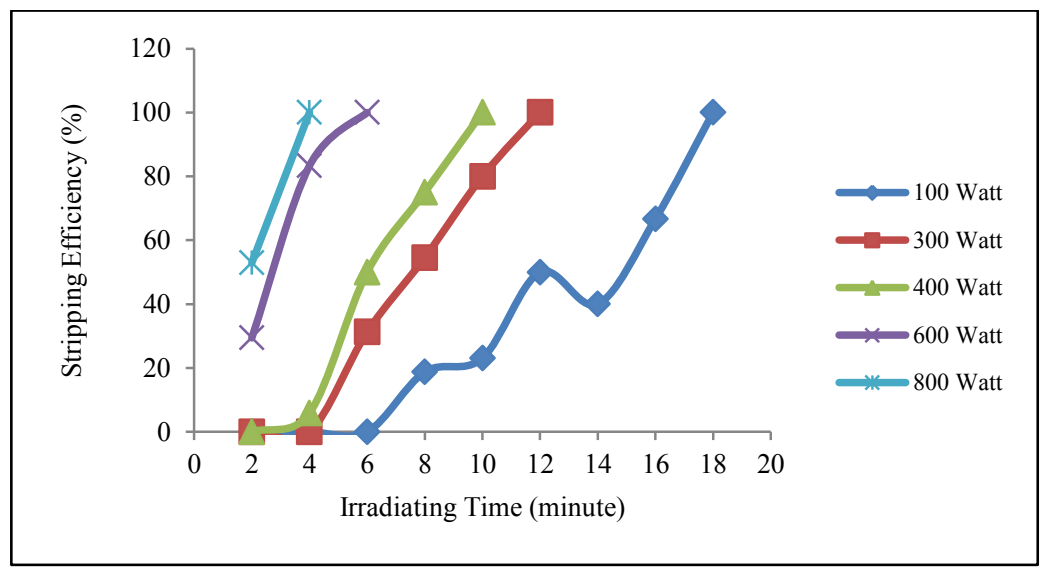

Figure 1. Effects on stripping efficiency of oil palm spikelet in relation various microwave power level of 100 to 800 Watt

Determination of microwave power level was decided after conducting several preliminary works, where researcher discovered that, the highest power level (1000 Watt) will contribute to low fruits quality, on the other hand at low power level (300 and 100 Watt) will be responsible for lengthy of time required for fruit detachments. As can be seen, power level workedin this study is medium level, within the range of 400, 600 and 800 Watt at irradiating time less than 10 minutes with oil palm fruits completely detached from the bunches. This results are similarly with previous work conducted by other researchers from $[12,21,22]$. These results also proved that microwave radiation is suitable to be used for fruit detachment from the bunch since the abscission region has higher dielectric properties [18] due to high moisture content as compared to other parts of the fruitlet. The high moisture content and conduction loss from ionic constituents were the two main contributing factors. Their results indicated that the ultimate of the moisture content is exactly positioned at the abscission region. Undeniably, the moisture content under a microwave treatment is important, since water is an excellent absorber of microwave energy [26]. This strong absorption provides the increase of the temperature inside the sample and then the break of the mesocarp positioned at pedicel by the in-situ water known as abscission zone [27], followed by the evaporation of water vapour. For that reason, the proposed microwave power level that will applicable in this research is medium range 400,600 and 800 Watt.

\section{Effect of water ratio on stripping efficiency}

The purpose of addition of waterto fruits spikelet is to implement a combined system that using combinations moisture heat with microwave with the intention of sterilisation can be carried at shorter time with $100 \%$ fruits stripping efficiency and give good quality of CPO. Figure 2 exhibits effect on irradiating time in relation to fruit mass to water volume at with 1:0, 1:1 and 1:2 (m:v). As can be observed, power level worked in this study is medium level, within the range of 400, 600 and 800 Watt. Obviously, at microwave power 400 Watt, it takes lengthy time to reach completely fruits detached with ratio of fruit mass to water volume at 1:2. Waves are absorbed 
by the oil palm spikelets, some are reflected and the remaining unabsorbed power is dissipated into the water vessel, which is placed in a container in the microwave cavity. The microwave powers lower than $450 \mathrm{~W}$ were in favour of the best water retention capacities [28].

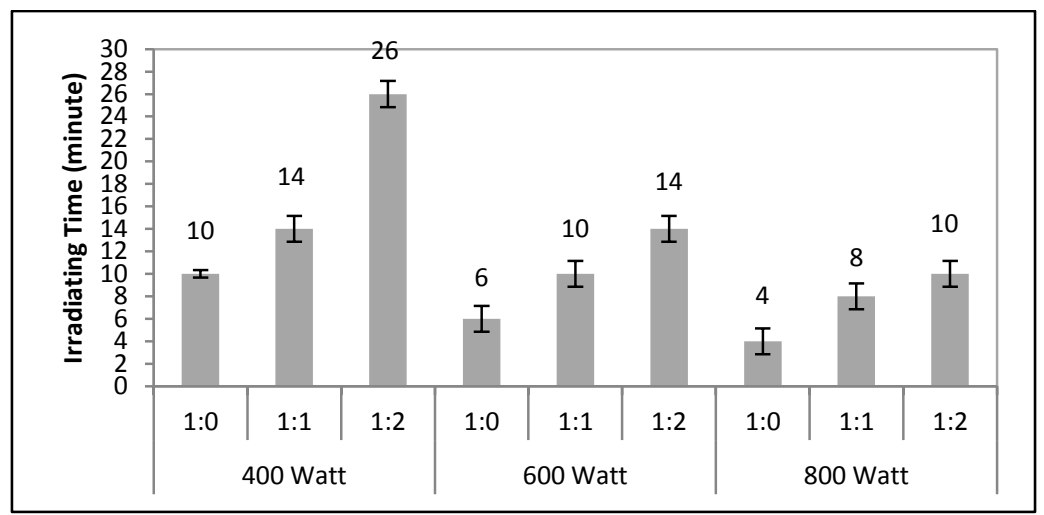

Figure 2. The irradiating time from medium power levels of microwave sterilization. Ratio fruit mass to water volume at with 1:0, 1:1 and 1:2(m:v)

Definitely, the moisture content under a microwave treatment is critical, since water is an outstanding absorber of microwave energy [26 - 29]. This strong absorption delivers the increase of the temperature inside the sample and then the rupture of the mesocarp and kernel cells by the in situ water, followed by the evaporation of water vapour. However, huge water adding in the vessel will interfere the stripping process time the oil palm fruits. To the best of our knowledge, implementation a combined system that using combinations moisture heat with microwave technique has never been applied for the oil palm fruits sterilisation. For that reason, through adding water will improve the kernel condition and mesocarp as well.

\section{Effect of microwave exposure on quality of palm oil}

The quality of crude palm oil (CPO) can be indicated from chemical properties such as free fatty acids content. Figure 3 presented FFA percentage with medium range power level microwave and ratio. CPO normally contains free fatty acids which need to be eliminated as part of the refining process. Obviously, Figure 3 summarizes at power $600 \mathrm{~W}$ and $800 \mathrm{~W}$ the maximum free fatty acids percentage are 4.04 and 4.08 , respectively with ratio 1:0. As can be seen also in the Figure 3, the trend of FFA percentage increased at 400 Watt. However, after increasing microwave power the FFA trend percentage was decreased. Throughout the trial, the quality of the oil extracted from the oil palm fruit spikelets in terms of the free fatty acid percentage was acceptable i.e below 5\%, varying from 1.02 to $4.08 \%$. However it should be kept as low as possible for nicer oil quality of palm oil and lower refining cost [28 - 30]. It is also important in oil extraction to have an suitable microwave irradiation power setting as high power can degrade volatile compounds and the plant material itself $[30,31]$. The fruits consequently need to be heated immediately after harvest to inactivate the lipase and to prevent an unacceptable level of free fatty acids in the oil. The enzyme is activated upon abscission of the fruit and also when the fruit is bruised. 


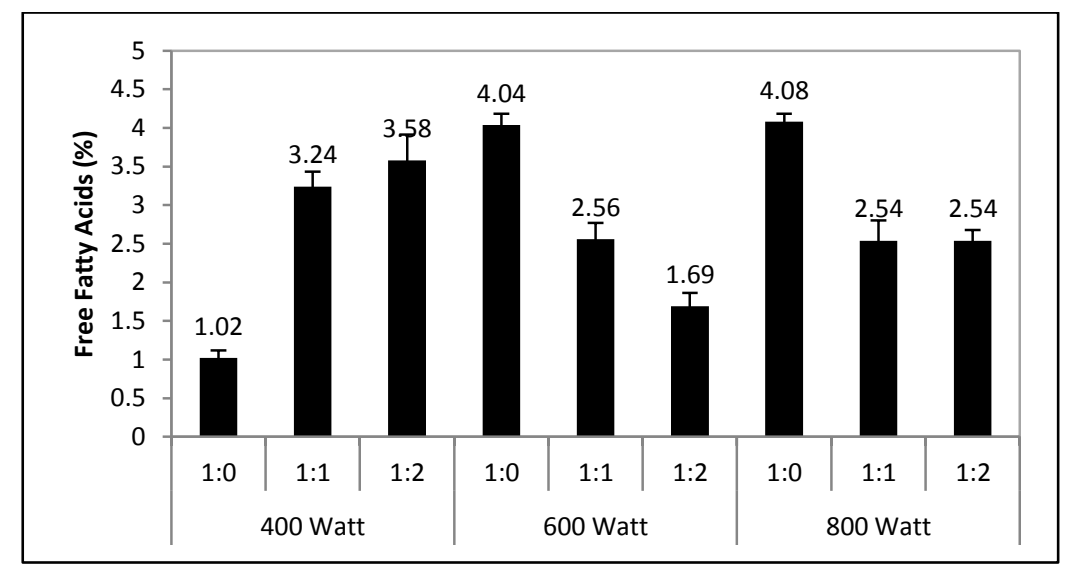

Figure 3. Effects of different fruit mass to water volume ratio on free fatty acids percentage. Microwave sterilised process was performed at different: irradiation power in medium range 400, 600 and $800 \mathrm{Watt}$

Physical appearance of microwave treated palm fruits

Table 1 indicates the physical appearance of oil palm spikelet in relation to microwave heating period at water ratio $1: 0$ and 1:0.5. The extension of microwave exposure with fruit to water ratio $(\mathrm{m}: \mathrm{v})$ of 1:0.5 was not discovered to burn kernel and mesocarp as observed in Table 1 even though at 800 Watt. The purpose of studying minimal water to the oil palm fruit spikelets is to distinguish the kernel condition once microwave irradiation. Production of water vapour and caramel-like aroma was also recognised for all microwavable exposure conditions. The removal of water was part of the heating process $[32,21]$. Indeed, the moisture content under a microwave treatment is critical, since water is an excellent absorber of microwave energy [36]. This mechanism is led to the drying effect and justifiable for the cracked, hardened and desiccated mesocarp [3].

Table 1. Physical appearance of oil palm fruits after microwave sterilisation by: (a) 1:0, (b) 1:0.5 ratio

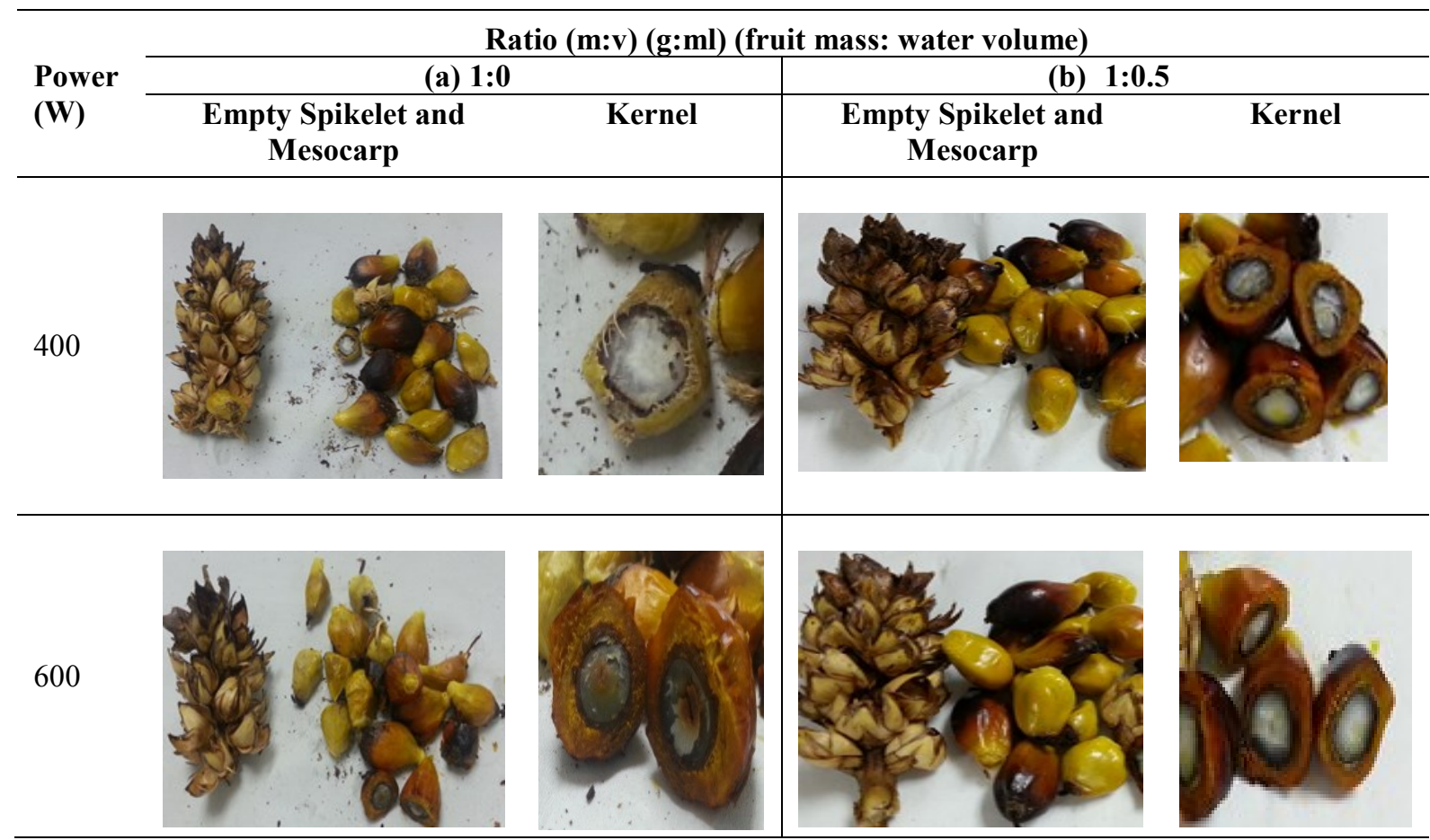


Table 1 (cont'd). Physical appearance of oil palm fruits after microwave sterilisation by: (a) 1:0, (b) 1:0.5 ratio

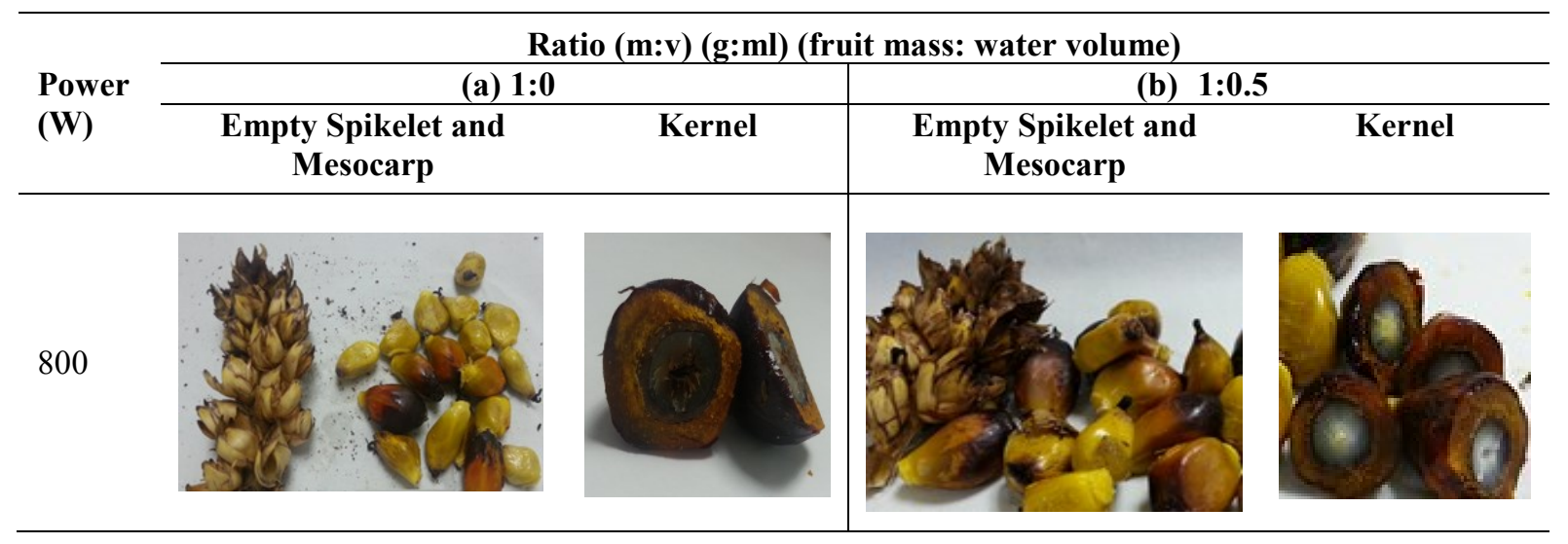

The mesocarp of fresh palm fruits has a fibrous-like texture which is yellowish- orange, hard and possesses a sweet fragrant. The seed or kernel is a single, hard and white in colour. As the exposure duration was extended with water ratio 1:0, there was significant increase in drying, cracking and browning effect on the mesocarp and kernel especially. It was observed that microwave exposure has greater effect on the kernel than mesocarp [25, 37]. There was almost slight drying and browning effect upon 2 min exposure with various power level and fruit mass to water ratio (m:v). Although kernels started to turn brown and appeared drier after several minute of exposure with fruit to water ratio of 1:0.5, 1:1 and 1:2, the mesocarp undergoes negligible browning. Therefore, thecondition and appearance of microwave exposed oil palm fruits after reaching $100 \%$ strip from the spikelets at 800 Watt and ratio 1:0.5 were denoted in Table 1(b). It shows good quality of white in colour kernel as compared to kernel in Table 1(a) at same power level.

\section{Conclusion}

In this research paper, the effect of using various power leveland ratio of fruit to water as well as analyze the quality of extracted oil have been presented and discussed. It has been shown that, medium power range of 400, 600 and 800 Watt enhance the stripping efficiency with shorter irradiating time. The optimum condition of this research was 6 min of irradiating time at 800 Watt and 1:0.5 ratio to reach completely fruit loosening and exhibits good quality of white in colour kernel with $4.08 \%$ of FFA. It was found that the microwave sterilisation can be completed at shorter time with $100 \%$ fruits stripping efficiency supplementary with minimum water ratio and this suggests further works especially on the understanding of the microwave interaction with the spikelet during irradiation with the intention ofextraction the oil. During the experimental, the quality of the oil extracted in terms of the free fatty acid percentage was acceptable, varying from 1.02 to $4.08 \%$. With the help of microwave mechanism, in future clean crude palm oil extraction can be done completed without toxic organic solvents in minutes instead of hours with various advantages.

\section{Acknowledgement}

The authors gratefully acknowledge the financial support received from Ministry Higher Education of Malaysia through Research Acculturation Grant Scheme (RAGS) (600-RMI/RAGS 5/3 (77/2013)), Lestari (600IRMI/DANA 5/3/LESTARI (0033/2016)), Research Management Institute (RMI) and Faculty of Chemical Engineering, Universiti Teknologi MARA, Shah Alam, Selangor, Malaysia.

\section{References}

1. Osei-Amponsah, C., Visser, L., Adjei-Nsiah, S., Struik, P. C., Sakyi-Dawson, O. and Stomph, T. J. (2012). Processing practices of small-scale palm oil producers in the Kwaebibirem District, Ghana: A diagnostic study. NJAS-Wageningen Journal of Life Sciences, 60: 49 - 56. 
2. Awalludin, M. F., Sulaiman, O., Hashim, R. and Nadhari, W. N. A. W. (2015). An overview of the oil palm industry in Malaysia and its waste utilization through thermochemical conversion, specifically via liquefaction. Renewable and Sustainable Energy Reviews, 50: 1469 - 1484.

3. Vincent, C. J., Shamsudin, R. and Baharuddin, A. S. (2014). Pre-treatment of oil palm fruits: A review. Journal of Food Engineering, 143: 123 - 131.

4. Hansen, S. B., Padfield, R., Syayuti, K., Evers, S., Zakariah, Z. and Mastura, S. (2015). Trends in global palm oil sustainability research. Journal of Cleaner Production, 100, 140 - 149.

5. Basiron, Y. and Weng, C. K. (2004). The oil palm and its sustainability. Journal of Oil Palm Research, 16(1): 1 -10 .

6. Lam, M. K. and Lee, K. T. (2011). Renewable and sustainable bioenergies production from palm oil mill effluent (POME): win-win strategies toward better environmental protection. Biotechnology Advances, 29(1): $124-141$.

7. Owolarafe, O. K. and Oni, O. A. (2011). Modern mill technology and centralised processing system, an alternative for improving performance of palm oil mills in Abia State, Nigeria. Technology in Society, 33(1): 12 -22 .

8. Ahmad, A. L., Ismail, S. and Bhatia, S. (2003). Water recycling from palm oil mill effluent (POME) using membrane technology. Desalination, 157(1-3): 87 - 95.

9. Sanagi, M. M., See, H. H., Ibrahim, W. A. W. and Naim, A. A. (2005). Determination of carotene, tocopherols and tocotrienols in residue oil from palm pressed fiber using pressurized liquid extraction-normal phase liquid chromatography. Analytica Chimica Acta, 538(1): 71 - 76.

10. Sivasothy, K., Hwa, R. M. T. T. Y. and Basiron, Y. (2006). Continuous sterilization: The new paradigm for modernizing palm oil milling. Journal of Oil Palm Research, 2006: $144-152$.

11. Norulaini, N. N., Ahmad, A., Omar, F. M., Banana, A. A. S., Zaidul, I. M. and Kadir, M. O. A. (2008). Sterilization and extraction of palm oil from screw pressed palm fruit fiber using supercritical carbon dioxide. Separation and Purification Technology, 60(3): $272-277$.

12. Chow, M. C. and Ma, A. N. (2007). Processing of fresh palm fruits using microwaves. Journal of Microwave Power and Electromagnetic Energy, 40(3), 165 - 173.

13. Fatin, S. A., Rosnah, S. and Yunus, R. (2014). Effect of chopping oil palm fruit spikelets on the free fatty acid content release rate and its mechanical properties. International Journal of Research in Engineering and Technology, 3(1): $511-516$.

14. Tan, C. H., Ghazali, H. M., Kuntom, A., Tan, C. P. and Ariffin, A. A. (2009). Extraction and physicochemical properties of low free fatty acid crude palm oil. Food Chemistry, 113(2), $645-650$.

15. Cheng, S. F. and Chuah, C. H. (2011). Microwave pretreatment: A clean and dry method for palm oil production. Industrial Crops and Products, 34(1): 967 - 971.

16. Sarah, M. and Taib, M. R. (2013). Microwave sterilization of oil palm fruits: Effect of power, temperature and d-value on oil quality. Journal of Medical and Bioengineering, 2(3): 129 - 133.

17. Ali, F. S., Shamsudin, R. and Yunus, R. (2014). The effect of storage time of chopped oil palm fruit bunches on the palm oil quality. Agriculture and Agricultural Science Procedia, 2: 165 - 172.

18. Sukaribin, N. and Khalid, K. (2009). Effectiveness of sterilisation of oil palm bunch using microwave technology. Industrial Crops and Products, 30(2): 179 - 183.

19. Arimi, J. M., Duggan, E., O’Sullivan, M., Lyng, J. G. and O'Riordan, E. D. (2010). Effect of moisture content and water mobility on microwave expansion of imitation cheese. Food Chemistry, 121(2), $509-516$.

20. McLoughlin, C. M., McMinn, W. A. M., \& Magee, T. R. A. (2000). Microwave drying of pharmaceutical powders. Food and Bioproducts Processing, 78(2): 90 - 96.

21. Bayramoglu, B., Sahin, S. and Sumnu, G. (2008). Solvent-free microwave extraction of essential oil from oregano. Journal of Food Engineering, 88(4): 535 - 540.

22. Zhao, S. and Zhang, D. (2014). Supercritical $\mathrm{CO}_{2}$ extraction of Eucalyptus leaves oil and comparison with Soxhlet extraction and hydro-distillation methods. Separation and Purification Technology, 133: 443 - 451.

23. Siew, W. L., Tan, Y. A. and Tang, T. S. (1995). Methods of test for palm oil and palm oil products: Compiled by Siew Wai Lin, Tang Thin Sue, Tan Yew Ai. Palm Oil Research Institute of Malaysia.

24. Sarah, M., Taib, M. R. and Adamu, A. (2014). Enzymatic inactivation of oil palm fruits: Comparison of microwave irradiation and steam bath process. Jurnal Teknologi, 65: $55-60$. 
25. Nokkaew, R. and Punsuvon, V. (2014). Sterilization of oil palm fruits by microwave heating for replacing steam treatment in palm oil mill process. Advanced Materials Research, 1025: 470 - 475.

26. Lucchesi, M. E., Chemat, F. and Smadja, J. (2004). Solvent-free microwave extraction of essential oil from aromatic herbs: comparison with conventional hydro-distillation. Journal of Chromatography A, 1043(2): 323 327.

27. Li, Y., Fabiano-Tixier, A. S., Vian, M. A. and Chemat, F. (2013). Solvent-free microwave extraction of bioactive compounds provides a tool for green analytical chemistry. TrAC Trends in Analytical Chemistry, 47: $1-11$.

28. Ghanem, N., Mihoubi, D., Kechaou, N. and Mihoubi, N. B. (2012). Microwave dehydration of three citrus peel cultivars: Effect on water and oil retention capacities, color, shrinkage and total phenols content. Industrial Crops and Products, 40: $167-177$.

29. Virot, M., Tomao, V., Ginies, C., Visinoni, F. and Chemat, F. (2008). Microwave-integrated extraction of total fats and oils. Journal of Chromatography A, 1196: 57 - 64.

30. Benmoussa, H., Farhat, A., Romdhane, M. and Bouajila, J. (2016). Enhanced solvent-free microwave extraction of Foeniculum vulgare Mill. essential oil seeds using double walled reactor. Arabian Journal of Chemistry, Article in Press.

31. Chong, C. L. and Sambanthamurthi, R. (1993). Effects of mesocarp bruising on the rate of free fatty acid release in oil palm fruits. International Biodeterioration \& Biodegradation, 31(1): 65 - 70.

32. Mba, O. I., Dumont, M. J. and Ngadi, M. (2015). Palm oil: Processing, characterization and utilization in the food industry-A review. Food bioscience, 10: $26-41$.

33. Takagi, S. and Yoshida, H. (1999). Microwave heating influences on fatty acid distributions of triacylglycerols and phospholipids in hypocotyl of soybeans (glycine max L.). Food Chemistry, 66(3), 345 - 351.

34. Filly, A., Fernandez, X., Minuti, M., Visinoni, F., Cravotto, G. and Chemat, F. (2014). Solvent-free microwave extraction of essential oil from aromatic herbs: from laboratory to pilot and industrial scale. Food Chemistry, 150: $193-198$.

35. Chandrasekaran, S., Ramanathan, S. and Basak, T. (2013). Microwave food processing-A review. Food Research International, 52(1): $243-261$.

36. Lucchesi, M. E., Smadja, J., Bradshaw, S., Louw, W. and Chemat, F. (2007). Solvent free microwave extraction of Elletaria cardamomum L.: A multivariate study of a new technique for the extraction of essential oil. Journal of Food Engineering, 79(3): 1079 - 1086.

37. Umudee, I., Chongcheawchamnan, M., Kiatweerasakul, M. and Tongurai, C. (2013). Sterilization of oil palm fresh fruit using microwave technique. International Journal of Chemical Engineering and Applications, 4(3), $111-113$. 